The University of Akron

\title{
IdeaExchange@UAkron
}

Proceedings from the Document Academy

University of Akron Press Managed

June 2017

\section{Beyond the Dawn: Authenticity, Documentation, and Kate Bush}

Edward Luca

edward.luca@sydney.edu.au

Please take a moment to share how this work helps you through this survey. Your feedback will be important as we plan further development of our repository.

Follow this and additional works at: https://ideaexchange.uakron.edu/docam

\section{Recommended Citation}

Luca, Edward (2017) "Beyond the Dawn: Authenticity, Documentation, and Kate Bush," Proceedings from the

Document Academy: Vol. 4 : Iss. 1 , Article 20.

DOI: https://doi.org/10.35492/docam/4/1/20

Available at: https://ideaexchange.uakron.edu/docam/vol4/iss1/20

This Article is brought to you for free and open access by University of Akron Press Managed at IdeaExchange@UAkron, the institutional repository of The University of Akron in Akron, Ohio, USA. It has been accepted for inclusion in Proceedings from the Document Academy by an authorized administrator of

IdeaExchange@UAkron.For more information, please contact mjon@uakron.edu, uapress@uakron.edu. 
In the liner notes for Before the Dawn, Kate Bush simply writes: 'This is the audio document.' Released in 2016, this live CD captures Bush's acclaimed concert series performed at the Hammersmith Apollo, London, in 2014. Bush goes on to detail her self-imposed constraints: 'Nothing at all has been re-recorded or overdubbed on this live album, just two or three sound FX added to help with the atmosphere.' The shows were her first in 35 years, and I was fortunate enough to be able to attend.

Produced and cut together by Bush herself, the CD delivers the definitive aural experience of the live performances. Bush cuts lines of dialogue, chops up transition sequences and rearranges passages that would be meaningless without their accompanying onstage performances. But has Bush really given us an audio document of her live shows, or has she created something new in the process?

After the sporadic release of one album in 1993 and another in 2005, Bush brought out two in 2011: Director's Cut and 50 Words for Snow. The former offered a selection of songs from The Sensual World (1989) and The Red Shoes (1993). Bush describes the process in her liner notes:

'Keeping the best original performances from the musicians but stripping out the tracks, adding new scenes and textures before sewing it all back together, it has become something of a director's cut but in sound - not vision.'

Director's Cut is useful context, as it reflects Bush's desire to control every aspect of production, self-curating and preserving her legacy. 2011 felt as if we were on the cusp of some sort of Kate Bush renaissance, but no-one would have ever entertained the thought of Bush returning to the stage. We were so wrong.

Before the Dawn represents the culmination of decades of work. In interviews, Bush describes the work as adding layers to layers, of honing an already incredible selection of material and imbuing them with new sounds, colors and textures. Bush, barefoot, guides her audience through a set of her more well-known hits, before performing the entirety of two stunning conceptual albums: The Ninth Wave and $A$ Sky of Honey.

Descriptions of the shows often point to bizarre and sometimes disturbing images: skeletal fish people dragging our shipwrecked heroine into the sea, giant projections of slow-motion birds, a helicopter aggressively scanning the theater, and a cannon shooting out 
passages of text from Tennyson's The Coming of Arthur. The greatest joy of all: being in the same room as Kate Bush. And having absolutely no idea what could possibly be coming next.

In the lead up to the shows, Bush posted a message on her website asking audiences not to take photos or film: 'I very much want to have contact with you as an audience, not with iphones, ipads or cameras. I know it's a lot to ask but it would allow us to all share in the experience together.'

This request made the entire event feel as if it had all been a bit of a dream. Audiences dutifully obeyed and once the shows ended, finding any sort of recording online became almost impossible. Two of the evenings were filmed for what was presumed to be an inevitable DVD release, but Bush vanished almost as quickly as she had reappeared.

Months later I came across a bootleg recording online and was unsure how to react. Was this the right way to revisit the Dawn? Surely Kate Bush herself would not approve of the recordings. It didn't take long, however, before I folded and had to listen. Like an addict I began to collect these bootleg recordings, comparing and contrasting the different shows. These recordings were all I had.

Almost two years later on Friday the 25th of November, 2016, Before the Dawn arrived. Matching my memories and the bootlegs with this new audio document was a strange experience. The CD reminds me of the promotional artwork for Director's Cut: Bush with a pair of scissors, carefully examining a roll of tape of her previous albums.

The audio is immaculate, with careful mixing ensuring that each instrument and voice is clearly discernible. Careful decisions were made about which take to use for which passage, yet the album still sounds raw and authentic. Bush's vocal work is astonishing. The audience fades in where appropriated and disappears where their presence would maybe disrupt the atmosphere.

Had I not listened religiously to the bootleg recordings, I'm not sure I would have noticed a range of small edits scattered across the three discs. A few lines of dialogue here and there, shortening the playlet sequences. An extended percussion part no longer segues us into King of the Mountain. A macabre projection of a blackbird ripping at a corpse (or at least I think that's what it was), removed entirely.

Bush includes Never Be Mine, a song that was recorded at dress rehearsals but never made it in front of a live audience. The audience 
cheers, as if it had been performed after all. Is it right for the song to have been reintroduced halfway through the first act? As if it had been there all along? Perhaps it might be better placed separately at the end, a bonus track for those who did see the shows.

These decisions distance the 'audio document' from the concert series. Bush treats this $C D$ as if it were another project altogether, separating it from the context of the live performance and instead weaving a new hyperreality, masquerading as authenticity. Walter Benjamin writes about the uniqueness or 'aura' of a work of art, arguing 'that which withers in the age of mechanical reproduction is the aura... it substitutes a plurality of copies for a unique existence. ${ }^{11}$ The aura is a notion of authenticity; that a work of art is situated in a particular time and place. A reproduction, therefore, can never be fully present. I think that this is an interesting idea, as it means that this 'live' recording of Before the Dawn never actually happened.

Make no mistake. I adore this CD, and it offers me a way to share the shows with others, to give them a window into what was such an exhilarating and life-changing event for me. But as my memories of that euphoric night do fade, I worry that eventually this CD will become my version of Before the Dawn, a version which is now everybody's version. I'm scared that my Wednesday the 24th of September, 2014, could be replaced.

${ }^{1}$ Benjamin, W., Zorn, H., \& Arendt, H. (1999). Illuminations. London: Pimlico, p. 215. 